\title{
Potential Pharmacokinetics and Pharmacodynamics (PK-PD) Drug-Herbs Interactions (DHI) from Metformin and Traditional Medicines: A Literature Review
}

\author{
Asri Dwi Endah Dewi Pramesthi', Endang Lukitaningsih², Agung Endro Nugroho ${ }^{3, *}$
}

Asri Dwi Endah Dewi Pramesthi', Endang Lukitaningsih ${ }^{2}$, Agung Endro Nugroho ${ }^{3, *}$

'Master Program of Pharmaceutical Sciences, Faculty of Pharmacy, Universitas Gadjah Mada, Yogyakarta, 55281, INDONESIA. ${ }^{2}$ Department of Pharmaceutical Chemistry, Faculty of Pharmacy, Universitas Gadjah Mada, Sekip Utara, Yogyakarta 55281 INDONESIA.

${ }^{3}$ Department of Pharmacology and Clinical Pharmacy, Faculty of Pharmacy, Universitas Gadjah Mada, Sekip, Utara, Yogyakarta, 55281, INDONESIA.

\begin{abstract}
Introduction: Metformin given together with herbs in order to optimizing its mechanism of actions. The effect might be positive and vice versa. Interaction might occur pharmacokinetics or pharmacodynamically. The study aimed to review potential interaction of metformin and some herbs with various pharmacological activities. Methods: This literature review was conducted by collecting articles with keywords Metformin, Herb-drug Interaction, drug interaction, pharmacokinetics, pharmacodynamics, and pharmacology from international databases such as Science Direct, PubMed, Springer Link, and Scopus up to 2021. Results: Metformin with its various uses such as antidiabetic agent, an agent for reducing weight for patients that sensitive or even resistant to insulin, patients with obesity, anti-tumor agent, anti-cancer potential agent, and also has anti-aging potential. Metformin could interacted with drugs, herbs, and also some bioactive isolate. The interaction might occurs pharmacokinetically or pharmacodynamically. Pharmacokinetics interactions occurred during distribution and also excretion via transporters that metformin transported with This was shown as the elevated or lowered metformin levels in blood. Pharmacodynamic interactions can be seen as the lowering or elevated levels of glucose, $\mathrm{HbA}_{1 \mathrm{c}}$ and even the lipid profile in blood or plasma. Conclusion: According to this literature review, Metformin have potential interaction with drugs, herbs, and also some bioactive isolate. The interactions occur pharmacokinetically or pharmacodynamically. This study can be used as a established familiarity with and understanding the potential HDIs from Metformin and herbal products.

Key words: Drug-Herbs Interactions (DHIs), Metformin, Pharmacokinetics, Pharmacodynamics.
\end{abstract}

\section{Correspondence}

\section{Agung Endro Nugroho}

Department of Pharmacology and

Clinical Pharmacy, Faculty of Pharmacy,

Universitas Gadjah Mada, Sekip, Utara,

Yogyakarta, 55281, INDONESIA.

Phone No: (+62) 85643929723

E-mail: agungendronugroho@gmail.com

History

- Submission Date: 21-11-2021;

- Review completed: 21-11-2021;

- Accepted Date: 01-12-2021.

DOI : 10.5530/pj.2022.14.29

Article Available online

http://www.phcogj.com/v14/i1

Copyright

(c) 2022 Phcogj.Com. This is an openaccess article distributed under the terms of the Creative Commons Attribution 4.0 International license.

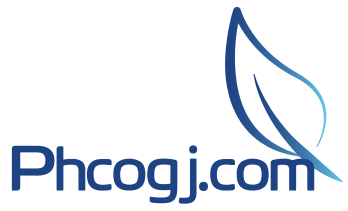

\section{INTRODUCTION}

The methylated biguanide ( $N, N$-dimethylimidodi carbonimicdiamide) mostly known as Metformin. Metformin first synthesized in Dublin, Ireland on 1922 by Werner and Dublin from the French lilac (Galega officinalis) that inadvertently has antihyperglycemic properties. ${ }^{1,2}$ It is considered as the gold standard that often firstly prescribed together with lifestyle modification after diabetes mellitus type 2 is diagnosed. ${ }^{3}$ As the glucose lowering agent, metformin could altered metabolic energy of the cell, reduced the absorption of glucose in intestinal, stimulated the free fatty acids oxidation and prevented lypolysis so insulin signaling is enhanced after suppressed lipotoxicity. ${ }^{4}$ Metformin also plays role in treating polycystic ovary syndrome (PCOS), treating obesity, intensify the glucose uptake to skeletal muscle, Alzheimer's disease, radiotherapy, atherosclerosis, and reduce risk of cancer. ${ }^{2,5,6}$

Having various mechanism of action, metformin has unique characteristics which is unmetabolised in the body. After absorption phase, it goes distributed and excreted afterwards in its active compounds. ${ }^{7}$ The interaction that occurs obviously different than others antidiabetic drugs, the CYP450 do not affect the metformin activity. Metformin could interact with drugs or substances that transported by OCT, PMAT, and MATE, since these transporters play major role in distribution of metformin in liver and kidney. ${ }^{8,9}$ Transporters not only works for transporting drugs and its active compound. It also works to transport active compound and also isolate from traditional medicine.

Traditional medicine such as Ayuverdic, Traditional Chinese Medicine, Jamu in Indonesia, and others common herbs is common used in Asia even worlwide. Using traditional medicine is no longer categorized as old-fashioned. Since now, there are so many drugs were made based on traditional used. ${ }^{10-}$ ${ }^{12}$ Given together with drugs, herbs could affect the mechanism of action of the drugs and gives positive or even negative effect afterwards. ${ }^{13}$ This kind of interaction might also occurs with drugs with some mechanism of action, like metformin. The interaction might affect pharmacodynamically or pharmacokinetically.

Since there are some mechanism of action of metformin, not only as the antidiabetics agent, as the tumor and its potency as anti-cancer and antiaging effects, and also treatment for PCOS, there are so many posibilities that interaction might occurs. ${ }^{1,14}$ Interaction between herbs and drugs between herbs and antidiabetic drugs have been reviewed in some paper. ${ }^{15-17}$ Drug-herb interaction that concentrated in metformin have not been published, so this review is aiming to give some informations about the DrugHerbs and Drug-Isolate Interactions in two main parts.

\section{METHODS}

This literature review was conducted by collecting relevant literature without restricting race, country
Cite this article: Pramesthi ADED, Lukitaningsih E, Nugroho AE. Potential Pharmacokinetics and Pharmacodynamics (PK-PD) Drug-Herbs Interactions (DHI) from Metformin and Traditional Medicines: A Literature Review. Pharmacogn J. 2022;14(1): 235-244. 
or origin. Searching method was done with keywords "Metformin" combined with either of the following MeSH terms: "Herb-drug Interaction", "Drug-Isolate Interaction", "drug interaction", "pharmacokinetics", "pharmacodynamics", and "pharmacology" to get related papers for sufficient review. It was done by international databases including Science Direct, Springer Link, Scopus, and PubMed up to September 2021. Additional lists of references were going through another screening and selection process to get relevant and most related to the question of interaction with metformin terms.

\section{RESULTS AND DISCUSSIONS}

\section{Drug-Herbs Interaction}

\section{Momordica charantia}

Drug-herb interaction that occurs with metformin, such as bitter gourd or BG (Momordica charantia) could enhanced the antidiabetic activity of metformin with unknown mechanism. Since metformin do not undergo metabolism in the body, bitter gourd do not affect the metabolism of metformin. ${ }^{18-20}$

In alloxan-induced diabetic mice given metformin alone or in combination with bitter gourd fruit juice (BGFJ) showed reducing in blood glucose level significantly $(p<0.05)$ after treated for 21 days. Bitter gourd fruit juice was made by $20 \mathrm{~g}$ bitter gourd and aquadest $(100 \mathrm{~mL})$ then heated for 5 minutes in high-powered microwave, homogenated and filtered by strainer to get the supernatant. ${ }^{18,21}$ The metformin dose was $500 \mathrm{mg}$ in human dose and bitter gourd fruit juice concentration was77.58 g/mL. ${ }^{18}$ Organ indexes shown significantly differences in stomach and spleen from every groups compared to normal group. After 21 days of treatment, the histology of the stomach showed complete severe erosion over the shortened and diffused gastric pit and hyperplasia with large keratinization in combination group compared to normal group. While giving bitter gourd fruit juice twice daily induced shock hipoglychaemia in mice. ${ }^{18,22}$

In streptozotocin-induced diabetic rats, BGFJ combined with metformin high and low dose could reduce the blood glucose significantly higher than metformin alone. The highest hypoglycemic activity shown in rats that were given BGFJ with high dose metformin. In diabetic rats that induced by alloxan, $300 \mathrm{mg} / \mathrm{kg}$ BG extract revealed as most effective dose than 75 and $150 \mathrm{mg} / \mathrm{kg}$ in short term studies. Those fixed dose then combined with metformin $15 \mathrm{mg} / \mathrm{kg}$, could decrease the blood glucose value significantly compared with normal group after four weeks. This combination also reduced the total cholesterol by $34.25 \%$, triglycerides by $11.92 \%$, and LDL-cholesterol by $57.73 \%$ also increased the HDL-cholesterol level by $55.48 \%$ compared by the control groups. This study suggested that combination of both as treatment for diabetes mellitus was more effective than mono-therapy. ${ }^{19,23}$

In type 2 diabetic patient, bitter gourd showed there is no difference for $\mathrm{HbAlc}$ levels from baseline and after 12 weeks treated by bitter gour standardized extract, while in placebo group, HbAlc levels showed significantly increased after 12 weeks of treatment compared to baseline. ${ }^{24}$ Bitter gourd fruit juice could also reduce the enhanced fasting plasma glucose in patients with prediabetes. It was used as supplementation with maximum daily dosage until $4.8 \mathrm{~g}$ is considered to be safe for humans. ${ }^{25}$ Bitter gourd $2000 \mathrm{mg} /$ day considered as best dose than $500 \mathrm{mg}$ and $1000 \mathrm{mg}$ daily as hypoglycemic agent based on fructosamine concetratrion decreased. The hyplogycemic effect of bitter gourd $2000 \mathrm{mg}$ daily was less than metformin $1000 \mathrm{mg}$ daily. ${ }^{22}$ Study about combination of bitter gourd and metformin in diabetic patient has not been conducted since the mechanism about the interaction of both have not been concluded.

\section{Brassica rapa}

Brassicacea family has major role in production and consumption in worldwide. Turnip leaf (Brassica rapa) used in Iran as traditional medicine for diabetes mellitus treatment. It has biologically active compounds such as flavonoids like isorhamnetin, phenylpropanoid derivates, indole alkaloids and sterol glycosides, while the beneficial effect as andiabetic activity, it has polyphenols and flavoinoids. ${ }^{26}$

Brassica rapa aqueous extract (AETL) alone or combined with metformin could reduce fasting blood glucose in diabetic rats after treated for 4 weeks. The groups that were treated with AETL alone or combined with metformin, compared to the diabetic control that were not treated or just given saline alone, showed decreasing in fasting blood glucose gradually and normal glucose level had been achieved in the fourth week. Combination of AETL and metformin showed agonist effect as glucose lowering agent significantly. Metformin 100 $\mathrm{mg} / \mathrm{kg}$ and AETL showed best combination in this study with no alterations in limphocyte infiltration, deposition fat in microvesicular, hemorrhage, and eosinopilic cytoplasm compared to other groups. AETL and metformin $100 \mathrm{mg} / \mathrm{kg}$ combination showed low alterations in sinusoidal dilatation. It is concluded that metformin given together with AETL showed positive interaction by decreasing the risk of liver injury. ${ }^{27}$

\section{Ginkgo biloba}

Ginkgo biloba (GKB) extract, a herbal dietary supplement that is sold as over-the-counter (OTC) product in United States and Europe. Given together with metformin in patients with or without T2DM that may used it daily for other purposes, could alter the pharmacokinetics properties of metformin. EGb 761 as single dose $120 \mathrm{mg}$ daily or placebo with vegetable-based for 3 months, and in the last day the patients were given metformin 250-850 mg before pharmacokinetics analysis. Urine and blood samples were used for pharmacokinetics analysis over an 8 hours period. ${ }^{28} \mathrm{EGb} 761$ could reduce the $\mathrm{HbA}_{1 \mathrm{c}}$ in T2DM subjects. While combined with metformin $500 \mathrm{mg}$ twice daily, could escalate the metformin plasma level and deflated metformin excretion in urinary. The $\mathrm{HbA}_{1 \mathrm{c}}$ that compared to baseline also decreased eventually. The combination could improve the effectivity of metformin seen by the outcomes in T2DM patients, such as decreasing in $\mathrm{HbA}_{1 \mathrm{c}}$, elevating the fasting blood glucose measure, and increasing insulin rate..$^{28,29}$

\section{Cocos nucifera}

Cocos nucifera inflorescence (CnI) contained of amino acids that potentially improved the $\beta$-cells pancreatic islets, tannins, and phenolic compounds that could regulate carbohydrate and lipids metabolism, alleviate hyperglycemia, insulin resistance, dyslipidemia, and rejuvenate the adipose tissue's metabolism. ${ }^{30} \mathrm{CnI}$ extract $(250-500 \mathrm{mg} / \mathrm{kg})$ were given to diabetic rats with metformin $(22.5 \mathrm{mg} / \mathrm{kg})$. After dosing with $\mathrm{CnI}$ and metformin, a test to check the insulin reacted sith orally given glucose at the mean time was performed and the blood was withdrawn at $15,30,60$ and 120 via retro-orbital sinus. The plasma glucose level decreased from day 0,14 and 28 significantly in metformin combined with $\mathrm{CnI} 500 \mathrm{mg} / \mathrm{kg}$ than positive group control. The OGTT showed that $\mathrm{CnI}$ with metformin combination could improve the glucose homestasis by decreasing the concentration of blood glucose at 20 and 60 minutes. Metformin and $\mathrm{CnI}$ with $500 \mathrm{mg} / \mathrm{kg}$ dose combination showed greater antidiabetic effects than other CnI doses. ${ }^{31}$

\section{Zingiber officinale}

Ginger (Zingiber officinale) has phenolic compound that could reduce LDL by increasing 7-hydroxylase enzyme that plays role as stimulator for cholesterol-bile acids changed. This mechanism plays important role in disease with metabolism correlations. Ginger could decrease the serum glucose level and regeration of beta pancreatic cells by its 
chemical constituents such as polyphenols, vitamin $\mathrm{C}, \beta$ carotene, flavonoids, and tannins. ${ }^{32,33}$ Ginger juice $2000 \mathrm{mg} / \mathrm{ml}$ combined with metformin once daily could decrease the value of glucose in blood in diabetic mice significantly than the normal groups. While given twice daily, it induced hypoglycemia in mice. Organ indexes showed that the liver were increased due to degeneration and accumulation of fluid in cell organeles in negative control compared to normal groups. Combination of ginger and metformin could reduce the liver damaged caused by diabetes mellitus. Ginger has hepatoprotector activity so it could decrease the cells degeneration by antioxidant activity and fibrosis did not appeared on the combination groups compared to negative control. ${ }^{32,34,35}$

\section{Aspalathus linearis}

Green rooibos (Aspalathus linearis) also known as GRT, the indigenous fynbos legume from South Africa with aspalathin as major bioactive compound plays role as antidiabetic agent. Aspalathin could augmenting the uptake of glucose in L6 myotubes. The AMPactivated protein kinase was activated and glucose translocated to the cell membrane through GLUT- 4 by asphalathin. ${ }^{36,37}$ When combined with metformin the pharmacokinetics parameters did not showed affected significantly and also the concentrations of metformin did not change significantly. It showed reducing in Tmax, Cmax, and AUC insignificantly and also increased insignificantly in $\mathrm{T}^{1} / 2 .{ }^{37}$ GRT could increase mRNA $A b c c 2$ expression significantly, while metformin downregulated the mRNA $A b c c 2$ expression. Combination metformin and GRT made mRNA $A b c c 2$ downregulated its expression. Since metformin is CYP450 independent, it depends on SLC transporters, like OCT and ABC transporters to showed its mechanism of action pharmacologically. ${ }^{38-40}$ The combination of both not affected of metformin pharmacokinetics profile specifically, and for the pharmacodynamic effect also insignificantly affected by combination compared to given metformin alone. ${ }^{37}$

\section{Andrographis paniculata}

Andrographis paniculata traditionally used as antidiabetic agent. Andrografolid as the main bioactive compound with bitter taste. Rats induced diabetes mellitus with high-fat-fructose diet given orally, purified extract of A. paniculata $434.6 \mathrm{mg} / \mathrm{kg}$ combined with metformin $2.5 \mathrm{mg} / \mathrm{kg}$ given twice daily could decrease the post-prandial glucose after 55 days compared to the $50^{\text {th }}$ days. Andrografolid had the same activity as metformin in stimulating the GLUT-4 transporter to transport glucose and increased the expression of mRNA and the protein level in GLUT-4 transporter to transport glucose through cell. ${ }^{41-43}$

\section{Lonicera japonica}

Lonicera japonica Thunb. (Caprifoliaceae) popularly known in East Asia, traditionally used for lowering heat, clearing thirst, remove toxic substances and even improving diabetic symptoms. It is confirmed to have pharmacological activities from its flowers and flower buds as antidiabetic agent. ${ }^{44,45}$ Etanolic extract of Lonicera japonica (LJ) was used in combination with metformin to determine their interaction pharmacokinetically and pharmacodynamically. Low concentration of LJ inhibited the MATE1 receptor that used for metformin uptake to the cell. While LJ high concentration inhibited metformin penetration to cell mediated by some transporters. Combination of LJ and metformin after its oral administration showed changed in pharmacokinetics profile and metformin concentration insignificantly after 1, 7 and 28 days. Metformin distribution to liver after 28 days consuming both combination showed significantly higher after 3 and 12 hours. The combination unaffected metformin distribution in renal significantly. So the combination of metformin and LJ escalated metformin concentration by inhibit liver MATE1 transporter and made intolerance glucose condition better. The glucose level showed no different significantly between groups that were given metformin alone or combination of both. ${ }^{45}$

\section{Nisha amalaki}

Nisha amalaki (NA), a formulation that contained of Curcuma longa Linn and Phyllanthus emblica Linn from Ayurvedic and Ninghantus. It is good for many diseases like also for diabetes. Combined with metformin, NA could affects metformin pharmacokinetics parameters. Co-administration NA at $200 \mathrm{mg} / \mathrm{kg}$ dose with metformin for 15 days, significantly increase the maximum concentration, maximum time concentration and infinity area under curve of metformin in contrast with metformin alone. It is also decreased the $\mathrm{V}_{\mathrm{d}}$ and CL significantly compared to only metformin. This combination could increase the insulin levels and reduce the AUC plasma glucose than diabetic group. ${ }^{46}$

\section{Plantago ovata}

Plantago ovata (PO) used as purified psyllium fibers in treatment of diseases. Fibers could affect the bioavailability of drugs that administered orally in gastrointestinal tracts. Psyllium also has hypoglycemic properties that might possibly contribute in lowering glucose level taken together with metformin. ${ }^{12}$ Metformin $30 \mathrm{mg} / \mathrm{kg}$ administered intravenously after orally supplemented with PO husk fiber in certain dose for 35 days to normal rabbits, compared to rabbits that supplemented with standard chow. This study were performed for analyzing the pharmacokinetics studies and the fiber supplement effect on metformin concentration in blood. ${ }^{47}$

The $\lambda, \mathrm{Cl}$ and MRT were insignificantly elevated at animal models supplemented with standard food in group that were given metformin intravenously. The glucose level and insulin concentrations also slightly higher in groups that were given with standard chow, but the differences is not significant. ${ }^{47}$ After metformin given orally, the concentration of metformin's mean plasma is also slightly higher in standard chow than supplemented chow. The AUC, Va/F, AUMC, MRT, and F are slightly higher in supplemented chow. ${ }^{47}$ Fibers could increase the absorption amount of metformin and also slowing the rates of absorption. Significant delayed on $t_{\max }$ was shown while fiber is administered. Dietary with Plantago ovata husk can can play a role in lowering glucose levels in treatment of hyperglycemia and type 2 diabetes mellitus. $^{47}$

\section{Scutellaria baicalensis}

Scutellaria baicalensis (SB) roots have been used traditionally in Eastern Asia as antioxidant, antiinflammatory, antiobesity, and antidiabetics agent. ${ }^{48}$ It is known as Traditional Chinese Medicine (TCM) that could improve the insensitivity of insulin and reduce total cholesterol of OLETF rats models while combined with metformin. In streptozotocin-induced diabetes rats, combined with metformin could improve hepatic antioxidant enzyme activity. ${ }^{49}$ Clinical study shows that both combination could improve glucose tolerance partially and expressing antiinflammatory effects by suppressing the immune modulators. $^{49}$

Scutellaria baicalensis has some bioactive components such as baicalein, baicalin, and wogonin that might interact with drugs that rely on SLCs, OAT, OATPs, and OCTs or OCTNs. ${ }^{48}$ It is suggested that it might interact with metformin since metformin transport depends on those transporters. SB might also interacted with metformin mediated by MATE1. ${ }^{50}$

\section{Catharanthus roseus}

Metformin and Catharanthus roseus (CR) combined together significantly increase the hypoglycemic effect of metformin. CR mainly used in cancer chemotherapy from its bioactive components such as vincristine, vinblastine, vinleurosin, and vinposidin. The presence of flavonoids, alkaloids, and saponins plays important role 
in hypoglycemic activity of CR. As observed in diabetic rats, CR has synergistic effect pharmacodynamically. It affected pharmacokinetically but insignificant. ${ }^{51}$

\section{Canna edulis}

Nutritional strategy for metabolic disease is very important for improving patient health. Resistant starch, novel dietary fibers that could also produced by Canna edulis. Canna edulis with $3^{\text {rd }}$ type of resistant starch (Ce-RS3) administered on T2DM rats exhibited similar antidiabetic effects as those which treated with metformin. The effect including reduced blood glucose, elevated insulin resistance test response and test for anlyzing tolerance in glucose, also reducing the T2DM impairment in rats that occurs pathologically. This combination escalated the diverse of gut bacterial and significantly increase ShortChain Fatty Acids (SCFA) levels on producing bacteria. ${ }^{52}$

\section{DRUG-ISOLATE INTERACTIONS}

\section{Curcuminoid}

Curcuminoid (CE) is a bioactive compounds that exist in Curcuma longa Linn. It is potentially possess a significant an antidiabetic effects. Co-administration with metformin significantly affects metformin's pharmacokinetics parameters such as the $C_{\max }, A U C_{\infty}$, and $T_{\max }$ of metformin compared to metformin alone. It is also decreased the $\mathrm{V}_{\mathrm{d}}$ and CL significantly compared to metformin alone. It is suggested that $\mathrm{CE}$ could affect the absorption and excretion of metformin. The possible mechanism is by inhibiting metformin transport through OCT. While pharmacodynamic interaction that occurs in diabetic rats model showed that maximum reduction in plasma glucose measurement occurred, could be seen from its AUC than the diabetic group. This combination also could reduce the triglycerides and HDL level significantly compared to untreated diabetic group. ${ }^{46}$

\section{Berberine}

Berberine as the main bioactive component from Rhizoma Coptidis have antidiabetic activity as hypoglycemic and insulin-sensitizing effects. It was analyzed while combined with metformin to make sure how is the interaction mechanism between both. Berberine inhibited metformin uptake by OCT1- and OCT2 based from its concentration after co-administration berberin with metformin. It also increased metformin initial concentration and AUC, decreased metformin systemic clearance and $\mathrm{Vd}$ in rats. This is suggested that berberine inhibited transport of metformin via OCT1 and OCT2 significantly. Two-hour pretreatment with berberine decreased the microbiota mediated degradation of metformin, so the in vivo bioavailability is higher. It could also increased the systemic exposure of metformin in body with 2 hours interval administration. ${ }^{53,54}$

\section{Methylmalonic acid}

One of metformin side effects is decreased of serum vitamin B12 that might because of tissue B12 deficiency but it remains controversial. Methylmalonic acid (MMA) is a marker of tissue B12 deficiency. Longterm placebo-controlled trial on metformin used together with MMA, showed that metformin reduce the serum levels of B12 and increased the MMA serum as well as homocysteine serum. ${ }^{55}$ The increasing of MMA serum in patients that taking metformin is correlated with significant worsening on validated clinical neropathy score. Metformin mechanism of action as the B12 lowering agent has been described in some papers. ${ }^{5-57}$

\section{Mangiferin}

Mangiferin could be found in variety of plans such as Mangifera indica L, Salacia spp., Iris unguicularis, Anemarrhena asphodeloides rhizoma, Bombax ceiba leaves. Its pharmacological properties including antioxidant, antimicrobial, anticancer, antiinflammatory, and antidiabetic activity. ${ }^{58}$ Mangiferin commercially prescribed as hypoglycemic agents with mechanism of action like dipeptidyl peptidase-4 inhibitor (DPP4-inhibitor). Given together metformin and mangiferin showed better glycemic control than treated with metformin or mangiferin only. It showed in animals or cells models with synergistic interaction. Both combinations could elevate overall diabetic conditions and suggest for clinical practice. ${ }^{59}$

\section{Tangeretin}

The flavonoid from Citrus sinensis fruit peels, Tangeretin have chemopreventive and chemosensitizer activities. ${ }^{60}$ Metformin as novel antiproliferative agent, combined with tangeretin to make the cells of breast cancer sensitized after resistant. ${ }^{61}$ Those combination was investigated and evaluated, and showed that the treatment combination triggered apoptosis and synergistically hindered cell proliferation in parental and resistant cells. This study showed, both combination force an inhibitory effect based on dose-dependent in the cancer cell lines and the cells corresponded to doxorubicin-resistant. The calculations of $\mathrm{IC}_{50}$ disclosed that resistant cells are sensitive to metformin preferable than parental counterpart. Metformin as energy restriction mimetic agents (ERMAs), combined with tangeretin could make resistant breast cancer cells sensitized. Both combination could decrease the rate and activity of $\mathrm{ABCC} 1$ and also $\mathrm{ABCB} 1$ pumps synergistically. ${ }^{61}$

\section{Swietenine}

Swietenine is the major compound of Swietenia macrophylla King (Meliaceae), a tetranortriterpenoid or limonoid. In diabetic patients, it could stabilized the blood glucose measurement. Metformin and swietenine as blood glucose lowering agent equally effective as metformin in certain dose in normal rats. While coadministration of swietenine significantly dropped the glucose level compared to non-diabetic group. Swietenine dose dependently could elevate the biomarkers such as glucose, LDL, total cholesterol, triglycerides, liver function test measurement, urea, also creatinine. Swietenine combined with metformin could increase the capacity of total antioxidant by increasing the malondialdehyde level and did not induced hypoglycemia, liver toxiticy or renal toxicity. The combination effectively control the blood glucose and lipid level, also protect liver and kidney from elevated blood gluse levels effect. ${ }^{62}$

\section{CONCLUSION}

Metformin with its various uses such as antidiabetic agent, an effective agent to lose weight for patients with insulin sensitivity problems, obesity patients, anti-tumor agent, anti-cancer potential agent, and also has anti-aging potential Metformin could interact with drugs, herbs, and also some bioactive isolate. The interaction might occur pharmacokinetically or pharmacodynamically. Pharmacokinetics interactions occurred during distribution and also excretion via transporters that metformin transported with. This was shown as the elevated or lowered metformin levels in blood. Pharmacodynamics interactions can be seen as the lowering or elevated levels of glucose, $\mathrm{HbA}_{1 \mathrm{c}}$ and even the lipid profile in blood or plasma. The drug-herbs and drug-isolate interaction are concluded in Table 1 and Table 2.

\section{AUTHOR'S CONTRIBUTION}

All authors contributed in the concept and design making in this study. Asri Dwi Endah Dewi Pramesthi contributed to collect data and write the review. Agung Endro Nugroho and Endang Lukitaningsih are contributed to critical review and confirmed the publication for the final version. 
Pramesthi ADED, et al.: Potential Pharmacokinetics and Pharmacodynamics (PK-PD) Drug-Herbs Interactions (DHI) from Metformin and Traditional Medicines: A Literature Review

Table 1: Study Drug-Herbs Interaction of Metformin and Herbs.

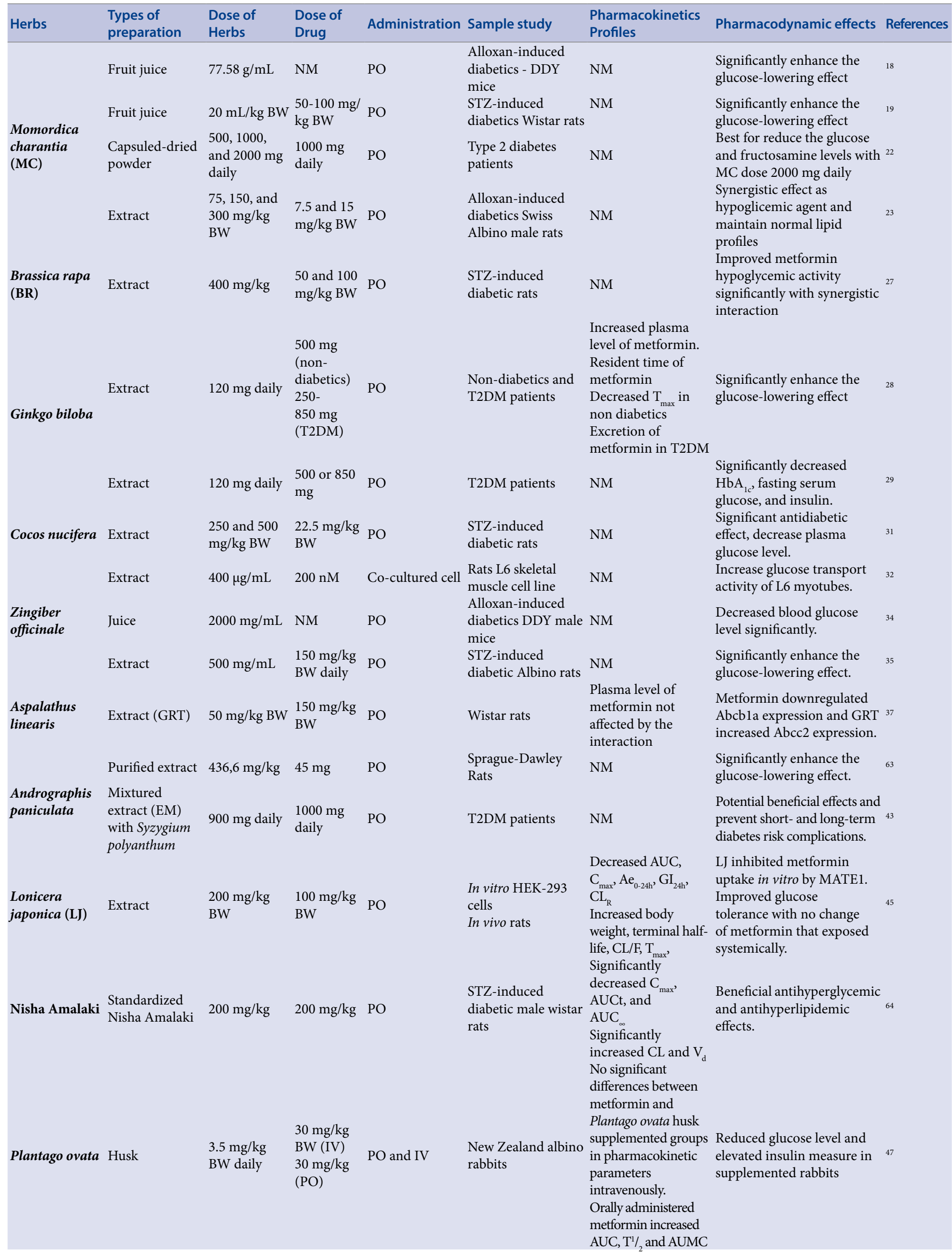




\begin{tabular}{|c|c|c|c|c|c|c|c|c|}
\hline \multirow[b]{2}{*}{$\begin{array}{l}\text { Scutellaria } \\
\text { baicalensis }\end{array}$} & $\begin{array}{l}\text { Capsulled } \\
\text { extract }\end{array}$ & $3.52 \mathrm{~g}$ & $500 \mathrm{mg}$ & $\mathrm{PO}$ & T2DM patient & NM & $\begin{array}{l}\text { Improved glucose tolerance } \\
\text { and inflammatory markers } \\
\text { expression in patient with } \\
\text { T2DM }\end{array}$ & 49 \\
\hline & Extract & $\begin{array}{l}200 \mathrm{mg} / \mathrm{kg} \\
\mathrm{BW}\end{array}$ & $\begin{array}{l}100 \mathrm{mg} / \mathrm{kg} \\
\text { BW }\end{array}$ & $\mathrm{PO}$ & $\begin{array}{l}\text { Sprague-Dawley } \\
\text { rats }\end{array}$ & NM & $\begin{array}{l}\text { Reduced biliary excretion } \\
\text { of metformin, enhanced } \\
\text { plasma lactate level. } \\
\text { Improved glucose } \\
\text { tolerance partially without } \\
\text { hypoglycemia. }\end{array}$ & 65 \\
\hline $\begin{array}{l}\text { Catharanthus } \\
\text { roseus }\end{array}$ & Extract & $\begin{array}{l}250 \mathrm{mg} / \mathrm{kg} \\
\mathrm{BW}\end{array}$ & $\begin{array}{l}100 \mathrm{mg} / \mathrm{kg} \\
\text { BW }\end{array}$ & $\mathrm{PO}$ & $\begin{array}{l}\text { Mice and albino } \\
\text { rats }\end{array}$ & NM & $\begin{array}{l}\text { Significantly increased } \\
\text { the hypoglycemic effect of } \\
\text { metformin }\end{array}$ & 51 \\
\hline Canna edulis & $\begin{array}{l}\text { Type } 3 \text { resistant } \\
\text { starch }\end{array}$ & $2 \mathrm{~g} / \mathrm{kg} \mathrm{BW}$ & $\begin{array}{l}300 \mathrm{mg} / \mathrm{kg} \\
\mathrm{BW}\end{array}$ & $\mathrm{PO}$ & $\begin{array}{l}\text { Sprague-Dawley } \\
\text { rats }\end{array}$ & NM & $\begin{array}{l}\text { Increased gut bacterial } \\
\text { diversity associated with } \\
\text { T2DM-related indexes, } \\
\text { alleviated diabetic } \\
\text { phenotype dysbioses, } \\
\text { improved metabolic control }\end{array}$ & 52 \\
\hline
\end{tabular}

$\mathrm{Ae}_{0-24 \mathrm{~h}^{\prime}}$ dose excreted in urine for $24 \mathrm{~h}$ in percentation; AUMC, area below the first momment curve; AUC, area under the plasma concentration-time curve;BW, body weight; $\mathrm{CL} / \mathrm{F}$, total body clearance; $\mathrm{CL}_{\mathrm{R}^{\prime}}$ renal clearance; $\mathrm{C}_{\text {max }}$, plasma peak concentration; $\mathrm{Gl}$, gastrointestinal tract; $\mathrm{Gl}_{24 \mathrm{~h}^{\prime}}$ dose recovered from the $\mathrm{Gl}$ at $24 \mathrm{~h}$ in percentation; NM, not mentioned; STZ, streptozotocin; T2DM, type 2 diabetes mellitus; $\mathrm{PO}$, per oral administration; $\mathrm{T}_{\text {max }}$, time to achieve; $\mathrm{T}^{1} / 2^{\prime}$, half-life elimination.

Table 2: Drug-Isolate Interactions of Metformin and Isolates.

\begin{tabular}{|c|c|c|c|c|c|c|c|c|}
\hline Isolates & $\begin{array}{l}\text { Types of } \\
\text { preparation }\end{array}$ & $\begin{array}{l}\text { Dose of } \\
\text { Isolate }\end{array}$ & $\begin{array}{l}\text { Dose of } \\
\text { Drug }\end{array}$ & Administration & Sample study & $\begin{array}{l}\text { Pharmacokinetics } \\
\text { Profiles }\end{array}$ & $\begin{array}{l}\text { Pharmacodynamic } \\
\text { effects }\end{array}$ & References \\
\hline Curcuminoid & Extract & $\begin{array}{l}30 \mathrm{mg} / \mathrm{kg} \\
\mathrm{BW}\end{array}$ & $\begin{array}{l}200 \mathrm{mg} / \\
\mathrm{kg} \mathrm{BW}\end{array}$ & $\mathrm{PO}$ & $\begin{array}{l}\text { STZ-induced diabetic } \\
\text { male wistar rats }\end{array}$ & $\begin{array}{l}\text { Significantly decreased } \\
\mathrm{C}_{\max }, \mathrm{AUCt} \text {, and } \\
\mathrm{AUC}_{\infty} \\
\text { Significantly increased } \\
\mathrm{CL} \text { and } \mathrm{V}\end{array}$ & $\begin{array}{l}\text { Beneficial } \\
\text { antihyperglycemic and } \\
\text { antihyperlipidemic } \\
\text { effects. }\end{array}$ & 46 \\
\hline \multirow[b]{2}{*}{ Berberine } & $\begin{array}{l}\text { Berberine } \\
\text { chloride isolate }\end{array}$ & $\begin{array}{l}200 \mathrm{mg} / \\
\mathrm{kg} \mathrm{BW}\end{array}$ & $\begin{array}{l}200 \mathrm{mg} / \\
\mathrm{kg} \mathrm{BW}\end{array}$ & $\mathrm{PO}$ & Sprague-Dawley Rats & $\begin{array}{l}\text { Increased } \mathrm{AUC}_{0-\infty}, \mathrm{T}^{1} 1{ }_{2}, \\
\text { and MRT. } \\
\text { Reduced CL/F. }\end{array}$ & $\begin{array}{l}\text { Significant effect } \\
\text { of sequential co-- } \\
\text { administration berberine and } \\
\text { metformin could be related } \\
\text { to the microbiota mediated } \\
\text { metabolisms in GI. }\end{array}$ & 54 \\
\hline & $\begin{array}{l}\text { Berberine } \\
\text { isolate }\end{array}$ & $\begin{array}{l}10 \mathrm{mg} / \mathrm{kg} \\
\mathrm{BW}\end{array}$ & $\begin{array}{l}2 \mathrm{mg} / \mathrm{kg} \\
\mathrm{BW}\end{array}$ & IV & $\begin{array}{l}\text { Male Sprague-Dawley } \\
\text { rats }\end{array}$ & $\begin{array}{l}\text { Increased initial plasma } \\
\text { concentration and AUC } \\
\text { of metformin. } \\
\text { Decreased systemic } \\
\text { clearance and volume } \\
\text { of distribution of } \\
\text { metformin. }\end{array}$ & $\begin{array}{l}\text { Berberine inhibited } \\
\text { activity of transporter } \\
\text { OCT1 and OCT2. }\end{array}$ & 66 \\
\hline $\begin{array}{l}\text { Methylmalonic } \\
\text { acid (MMA) }\end{array}$ & NM & NM & $\begin{array}{l}850 \mathrm{mg} \\
\text { daily }\end{array}$ & $\mathrm{PO}$ & T2DM patients & (1) & $\begin{array}{l}\text { Long-term placebo- } \\
\text { controlled trial showed } \\
\text { metformin progressively } \\
\text { increase serum MMA } \\
\text { and homocysteine. } \\
\text { It is associated with } \\
\text { significant worsening } \\
\text { of validated neuropathy } \\
\text { score. }\end{array}$ & 55 \\
\hline Mangiferin & $\begin{array}{l}\text { Mangiferin } \\
\text { isolate }\end{array}$ & $\begin{array}{l}40 \mathrm{mg} / \mathrm{kg} \\
\text { BW }\end{array}$ & $\begin{array}{l}100 \mathrm{mg} / \\
\mathrm{kg} \mathrm{BW}\end{array}$ & $\mathrm{PO}$ & $\begin{array}{l}\text { STZ-indiced diabetes } \\
\text { Sprague-Dawley rats } \\
\text { with HFD. } \\
\text { In vitro on HepG2 cells }\end{array}$ & NM & $\begin{array}{l}\text { In vitro study suggested } \\
\text { a positive interaction } \\
\text { on glucose uptake and } \\
\text { exhibited a potent } \\
\text { antidiabetic effect. }\end{array}$ & 59 \\
\hline Tangeretin & $\begin{array}{l}\text { Isolate } \\
\text { tangeretin }\end{array}$ & $\begin{array}{l}8.5-48 \\
\mu \mathrm{M}\end{array}$ & $\begin{array}{l}14.5-22 \\
\mathrm{mM}\end{array}$ & Injected to cells & $\begin{array}{l}\text { Breast cancer cell lines } \\
\text { (MCF-7, MDA-MB-23) } \\
\text { and its resistant } \\
\text { phenotype }\end{array}$ & NM & $\begin{array}{l}\text { Improve metformin } \\
\text { ability as anticancer both } \\
\text { in parental and resistant } \\
\text { cancer cells. }\end{array}$ & 61 \\
\hline Swietenine & $\begin{array}{l}\text { Isolate } \\
\text { swietenine }\end{array}$ & $\begin{array}{l}10,20, \\
\text { and } 40 \\
\mathrm{mg} / \mathrm{kg} \\
\text { BW }\end{array}$ & $\begin{array}{l}50 \mathrm{mg} / \\
\mathrm{kg} \mathrm{BW}\end{array}$ & $\mathrm{PO}$ & $\begin{array}{l}\text { STZ-induced diabetic } \\
\text { rats }\end{array}$ & NM & $\begin{array}{l}\text { Beneficial and synergistic } \\
\text { effects of swietenine with } \\
\text { metformin in controlling } \\
\text { the dysregulated serum } \\
\text { parameters. }\end{array}$ & \\
\hline
\end{tabular}

$\mathrm{Ae}_{0-24 \mathrm{~h}^{\prime}}$ dose excreted in urine for $24 \mathrm{~h}$ in percentation; $\mathrm{AUMC}$, area below the first momment curve; $\mathrm{AUC}$, area under the plasma concentrationtime curve; $\mathrm{BW}$, body weight; $\mathrm{CL} / \mathrm{F}$, total body clearance; $\mathrm{CL}_{\mathrm{R}^{\prime}}$ renal clearance; $\mathrm{C}_{\text {max' }}$ plasma peak concentration; $\mathrm{Gl}$, gastrointestinal tract; $\mathrm{Gl}_{24 h^{\prime}}$ dose recovered from the $\mathrm{Gl}$ at $24 \mathrm{~h}$ in percentation; NM, not mentioned; STZ, streptozotocin; T2DM, type 2 diabetes mellitus; PO, per oral administration; $\mathrm{T}_{\text {max }}$ time to achieve; $\mathrm{T}^{1} / 2^{\prime}$, half-life elimination. 


\section{CONFLICTS OF INTEREST}

The authors declare that there is no conflict of interest.

\section{ETHICAL CONSIDERATIONS}

Not applicable.

\section{FUNDING/SUPPORT}

The author would like to acknowledge the funding support from UGM No. 3143/UN1.P.III/DIT-LIT/PT/2021.

\section{REFERENCES}

1. Salvatore T, Pafundi PC, Morgillo F, et al. Metformin: An old drug against old age and associated morbidities. Diabetes Res Clin Pract. 2020;160:108025. doi:10.1016/j.diabres.2020.108025

2. Tien AY, Rea PA. Metformin: To the Brink and Back.; 2018 doi:10.1017/9781316459263.011

3. Upadhyay J, Polyzos SA, Perakakis N, et al. Pharmacotherapy of type 2 diabetes: An update. Metabolism. 2018:78:13-42. doi:10.1016/j.metabol.2017.08.010

4. Rena G, Hardie DG, Pearson ER. The mechanisms of action of metformin. Diabetologia. 2017;60(9). doi:10.1007/s00125-017-4342-z

5. Kinaan $M$, Ding $H$, Triggle CR. Metformin: An Old Drug for the Treatment of Diabetes but a New Drug for the Protection of the Endothelium. Med Princ Pract. 2015;24(5):401-415. doi:10.1159/000381643

6. Maniar K, Moideen A, Mittal A, Patil A, Chakrabarti A, Banerjee D. A story of metformin-butyrate synergism to control various pathological conditions as a consequence of gut microbiome modification: Genesis of a wonder drug? Pharmacol Res. 2017;117:103-128. doi:10.1016/j.phrs.2016.12.003

7. Graham GG, Punt J, Arora M, et al. Clinical pharmacokinetics of metformin. Clin Pharmacokinet. 2011;50(2):81-98. doi:10.2165/11534750-000000000-00000

8. Adak T, Samadi A, Ünal AZ, Sabuncuoğlu S. A reappraisal on metformin. Regul Toxicol Pharmacol. 2018;92(December 2017):324-332. doi:10.1016/j.yrtph.2017.12.023

9. Vanhove T, Remijsen Q, Kuypers D, Gillard P. Drug-drug interactions between immunosuppressants and antidiabetic drugs in the treatment of post-transplant diabetes mellitus. Transplant Rev. 2017;31(2):69-77. doi:10.1016/j.trre.2016.09.001

10. Dewi RS. Penggunaan Obat Tradisional Oleh Masyarakat D Kelurahan Tuah Karya Kota Pekanbaru. J Penelit Farm Indones. 2019;8(Vol 8 No 1 (2019)):41-45. http://ejournal.stifar-riau.ac.id/ index.php/jpfi/article/view/781

11. Xiao Z, Chen $Z$, Han $R$, et al. Comprehensive TCM treatments combined with chemotherapy for advanced non-small cell lung cancer: A randomized, controlled trial. Medicine (Baltimore). 2021;100(18):e25690. doi:10.1097/MD.0000000000025690

12. Ota A, Ulrih NP. An overview of herbal products and secondary metabolites used for management of type two diabetes. Front Pharmacol. 2017;8(JUL):1-14. doi:10.3389/fphar.2017.00436

13. Ulbricht C, Chao W, Costa D, Rusie-Seamon E, Weissner W, Woods J. Clinical Evidence of Herb-Drug Interactions: A Systematic Review by the Natural Standard Research Collaboration. Curr Drug Metab. 2008;9(10):1063-1120. doi:10.2174/138920008786927785

14. Podhorecka M, Ibanez B, Dmoszyńska A. Metformin - its potential anti-cancer and anti-aging effects. Postepy Hig Med Dosw (Online). 2017;71:170-175. doi:10.5604/01.3001.0010.3801

15. Han DG, Cho SS, Kwak JH, Yoon IS. Medicinal plants and phytochemicals for diabetes mellitus: pharmacokinetic characteristics and herb-drug interactions. J Pharm Investig. 2019:49(6):603-612. doi:10.1007/s40005-019-00440-4
16. Gupta RC, Chang D, Nammi S, Bensoussan A, Bilinski K, Roufogalis BD. Interactions between antidiabetic drugs and herbs: An overview of mechanisms of action and clinical implications. Diabetol Metab Syndr. 2017;9(1):1-12. doi:10.1186/s13098-017-0254-9

17. Maideen NMP, Balasubramaniam R. Pharmacologically relevant drug interactions of sulfonylurea antidiabetics with common herbs. J HerbMed Pharmacol. 2018:7(3):200-210. doi:10.15171/ jhp.2018.32

18. Pramesthi ADED, Ardana M, Indriyanti N. Drug-Herb Interaction between Metformin and Momordica charantia in Diabetic Mice. Mol Cell Biomed Sci. 2019;3(2):81. doi:10.21705/mcbs.v3i2.47

19. Poonam T, Prem Prakash G, Vijay Kumar L. Interaction of Momordica Charantia with metformin in diabetic rats. Am J Pharmacol Toxicol. 2013;8(3):102-106. doi:10.3844/ajptsp.2013.102.106

20. Ahmad N, Hasan N, Ahmad Z, Zishan M, Zohrameena S. Momordica Charantia: for Traditional Uses and Pharmacological Actions. J Drug Deliv Ther. 2016:6(2):40-44

21. Subramaniam S, Rosdi MHB, Kuppusamy UR. Customized cooking methods enhance antioxidant, antiglycemic, and insulin-like properties of Momordica charantia and Moringa oleifera. J Food Qual. 2017;2017. doi:10.1155/2017/9561325

22. Fuangchan $A$, Sonthisombat $P$, Seubnukarn $T$, et al. Hypoglycemic effect of bitter melon compared with metformin in newly diagnosed type 2 diabetes patients. J Ethnopharmacol. 2011;134(2):422-428. doi:10.1016/j.jep.2010.12.045

23. Islam M, Islam MS, Zannah S, Sadik G, Rashid M. Momordica charantia (Bitter melon) in Combination with Metformin Potentiates Hypoglycemic and Hypolipidemic Effects in Alloxaninduced Diabetic Rats. Bangladesh Pharm J. 2018;21(2):109-117. doi:10.3329/bpj.v21i2.37921

24. Kim SK, Jung J, Jung JH, et al. Hypoglycemic efficacy and safety of Momordica charantia (bitter melon) in patients with type 2 diabetes mellitus. Complement Ther Med. 2020;52(July):102524. doi:10.1016/j.ctim.2020.102524

25. Krawinkel MB, Ludwig C, Swai ME, Yang R yu, Chun KP, Habicht $\mathrm{SD}$. Bitter gourd reduces elevated fasting plasma glucose levels in an intervention study among prediabetics in Tanzania. J Ethnopharmacol. 2018;216:1-7. doi:10.1016/j.jep.2018.01.016

26. Hassanpour Fard M, Naseh G, Lotfi N, Hosseini SM, Hosseini M. Effects of aqueous extract of turnip leaf (Brassica rapa) in alloxaninduced diabetic rats. Avicenna J phytomedicine. 2015;5(2):148156. doi:10.22038/ajp.2015.3980

27. Hassanzadeh-Taheri M, Hassanpour-Fard M, Doostabadi M, Mood $\mathrm{H}$, Vazifeshenas-Darmiyan K, Hosseini M. Co-administration effects of aqueous extract of turnip leaf and metformin in diabetic rats. J Tradit Complement Med. 2018;8(1):178-183. doi:10.1016/j jtcme.2017.05.010

28. Kudolo GB, Wang W, Javors M, Blodgett J. The effect of the ingestion of Ginkgo biloba extract (EGb 761) on the pharmacokinetics of metformin in non-diabetic and type 2 diabetic subjects-A double blind placebo-controlled, crossover study. Clin Nutr. 2006;25(4):606616. doi:10.1016/j.clnu.2005.12.012

29. Aziz TA, Hussain SA, Mahwi TO, Ahmed ZA, Rahman HS, Rasedee A. The efficacy and safety of Ginkgo biloba extract as an adjuvant in type 2 diabetes mellitus patients ineffectively managed with metformin: A double-blind, randomized, placebo-controlled trial. Drug Des Devel Ther. 2018;12:735-742. doi:10.2147/DDDT.S157113

30. Golbidi S, Ebadi SA, Laher I. Antioxidants in the treatment of diabetes. Curr diabetes Rev. 2011;7(2):106-125. doi:10.1007/ s00547-005-2033-y

31. Kaur G, Sankrityayan H, Dixit D, Jadhav P. Cocos nucifera and metformin combination for modulation of diabetic symptoms in streptozotocin induced diabetic rats. J Ayurveda Integr Med. 2020;11(1):3-9. doi:10.1016/j.jaim.2017.02.006 
32. Noipha K, Ninla-Aesong P. Antidiabetic activity of zingiber officinale roscoe rhizome extract: An in vitro study. HAYATI J Biosci. 2018;25(4):160-168. doi:10.4308/hjb.25.4.160

33. Bi X, Lim J, Henry CJ. Spices in the management of diabetes mellitus. Food Chem. 2017;217:281-293. doi:10.1016/j. foodchem.2016.08.111

34. Amelia KR, Mita N, Indriyanti N. Pengaruh Interaksi Metformin dengan Perasan Jahe pada Kadar Glukosa Darah dan Organ Mencit Diabetes. Proceeding Mulawarman Pharm Conf. 2019:16-17.

35. Sangi SMA, Bawadekji A, Ali M Al. Comparative Effects of Metformin, Pleurotus ostreatus, Nigella Sativa, and Zingiber officinale on the Streptozotocin-induced Diabetes Mellitus in Rats. Pharmacogn Mag. 2018;14(55). doi:10.4103/pm.pm_108_18

36. Kamakura R, Son MJ, de Beer D, Joubert E, Miura Y, Yagasaki K. Antidiabetic effect of green rooibos (Aspalathus linearis) extract in cultured cells and type 2 diabetic model KK-Ay mice. Cytotechnology. 2015;67(4):699-710. doi:10.1007/s10616-014-9816-y

37. Patel O, Muller CJF, Joubert E, et al. Pharmacokinetic interaction of green rooibos extract with atorvastatin and metformin in rats. Front Pharmacol. 2019;10(October):1-8. doi:10.3389/fphar.2019.01243

38. Mannino GC, Andreozzi F, Sesti G. Pharmacogenetics of type 2 diabetes mellitus, the route toward tailored medicine. Diabetes Metab Res Rev. 2019;35(3):1-20. doi:10.1002/dmrr.3109

39. Becker ML, Pearson ER, Tkáčl. Pharmacogenetics of oral antidiabetic drugs. Int J Endocrinol. 2013;2013. doi:10.1155/2013/686315

40. Liang X, Giacomini KM. Transporters Involved in Metformin Pharmacokinetics and Treatment Response. J Pharm Sci. 2017:106(9):2245-2250. doi:10.1016/..xphs.2017.04.078

41. Syamsul ES, Nugroho AE, Pramono S. HERBA SAMBILOTO ( Andrographis paniculata ( Burn. F .) NESS .) DAN THE ANTIDIABETICS OF COMBINATION METFORMIN AND PURIFIED EXTRACT OF. Maj Obat Tradisonal. 2011;16(3):124-132.

42. Anwar K, Wigati D, Sudarsono, Nugroho AE. Blood glucose reduction of combination of Andrographis paniculata (Burm.f) Ness and Morinda citrifolia L. ethanolic extract in neonatal streptozotocin-induced Type 2 diabetes mellitus rats. Int Food Res J. 2017;24(5):2153-2160.

43. Widjajakusuma EC, Jonosewojo A, Hendriati L, et al. Phytochemica screening and preliminary clinical trials of the aqueous extract mixture of Andrographis paniculata (Burm. f.) Wall. ex Nees and Syzygium polyanthum (Wight.) Walp leaves in metformin treated patients with type 2 diabetes. Phytomedicine. 2019;55(1):137-147. doi:10.1016/j.phymed.2018.07.002

44. Han SY, You BH, Yim S, Chin Y, Choi YH. Effects of Lonicera japonica thunb on metformin pharmacokinetics, tissue exposure and pharmacodynamics in rats. Drug Metab Pharmacokinet. 2014;32(1):S92. doi:10.1016/j.dmpk.2016.10.354

45. Han SY, Chae HS, You BH, et al. Lonicera japonica extract increases metformin distribution in the liver without change of systemic exposed metformin in rats. J Ethnopharmacol. 2019;238(April):111892. doi:10.1016/j.jep.2019.111892

46. Shengule S, Kumbhare K, Patil D, Mishra S, Apte K, Patwardhan B. Herb-drug interaction of Nisha Amalaki and Curcuminoids with metformin in normal and diabetic condition: A disease system approach. Biomed Pharmacother. 2018;101(February):591-598. doi:10.1016/j.biopha.2018.02.032

47. Díez R, García JJ, Diez MJ, Sierra M, Sahagun AM, Fernández N Influence of Plantago ovata husk (dietary fiber) on the bioavailability and other pharmacokinetic parameters of metformin in diabetic rabbits. BMC Complement Altern Med. 2017;17(1):1-9. doi:10.1186/ s12906-017-1809-x
48. Xu F, Li Z, Zheng J, et al. The inhibitory effects of the bioactive components isolated from Scutellaria baicalensis on the cellular uptake mediated by the essential solute carrier transporters. J Pharm Sci. 2013;102(11):4205-4211. doi:10.1002/jps.23727

49. Shin NR, Gu N, Choi HS, Kim H. Combined effects of Scutellaria baicalensis with metformin on glucose tolerance of patients with type 2 diabetes via gut microbiota modulation. Am J Physiol - Endocrinol Metab. 2020;318(1):E52-E61. doi:10.1152/ ajpendo.00221.2019

50. Yim S, You BH, Chae HS, et al. Multidrug and toxin extrusion protein 1-mediated interaction of metformin and Scutellariae radix in rats. Xenobiotica. 2017;47(11):998-1007. doi:10.1080/00498254 .2016.1257836

51. Ohadoma SC, Michael HU. Effects of co-administration of methanol leaf extract of Catharanthus roseus on the hypoglycemic activity of metformin and glibenclamide in rats. Asian Pac J Trop Med. 2011;4(6):475-477. doi:10.1016/S1995-7645(11)60129-6

52. Zhang $\mathrm{C}, \mathrm{Ma} \mathrm{S}, \mathrm{Wu} \mathrm{J}$, et al. A specific gut microbiota and metabolomic profiles shifts related to antidiabetic action: The similar and complementary antidiabetic properties of type 3 resistant starch from Canna edulis and metformin. Pharmacol Res. 2020;159(September 2019):104985. doi:10.1016/j. phrs.2020.104985

53. Kwon M, Choi YA, Choi MK, Song IS. Organic cation transportermediated drug-drug interaction potential between berberine and metformin. Arch Pharm Res. 2015:38(5):849-856. doi:10.1007/ s12272-014-0510-6

54. Lyu $Y$, Zhang $Y$, Yang $M$, et al. Pharmacokinetic interactions between metformin and berberine in rats: Role of oral administration sequences and microbiota. Life Sci. 2019;235(August):116818. doi:10.1016/j.lfs.2019.116818

55. Out M, Kooy A, Lehert P, Schalkwijk CA, Stehouwer CDA. Long-term treatment with metformin in type 2 diabetes and methylmalonic acid: Post hoc analysis of a randomized controlled 4.3 year trial. J Diabetes Complications. 2018;32(2):171-178. doi:10.1016/j. jdiacomp.2017.11.001

56. Bherwani S, Ahirwar AK, Saumya AS, et al. The study of association of Vitamin B12 deficiency in type 2 diabetes mellitus with and without diabetic nephropathy in North Indian Population. Diabetes Metab Syndr Clin Res Rev. 2017;11:S365-S368. doi:10.1016/j. dsx.2017.03.017

57. Shurrab NT, Arafa ESA. Metformin: A review of its therapeutic efficacy and adverse effects. Obes Med. 2020;17(December 2019). doi:10.1016/j.obmed.2020.100186

58. Fomenko EV, Chi Y. Mangiferin modulation of metabolism and metabolic syndrome. BioFactors. 2016;42(5):492-503. doi:10.1002/ biof.1309

59. Sekar V, Mani S, Malarvizhi R, Nithya P, Vasanthi HR. Antidiabetic effect of mangiferin in combination with oral hypoglycemic agents metformin and gliclazide. Phytomedicine. 2019;59(November 2018):152901. doi:10.1016/j.phymed.2019.152901

60. Meiyanto E, Hermawan A, Anindyajati. Natural products for cancertargeted therapy: Citrus flavonoids as potent chemopreventive agents. Asian Pacific J Cancer Prev. 2012;13(2):427-436. doi:10.7314/APJCP.2012.13.2.427

61. Mdkhana B, Zaher DM, Abdin SM, Omar HA. Tangeretin boosts the anticancer activity of metformin in breast cancer cells via curbing the energy production. Phytomedicine. 2021:83/October 2020):153470. doi:10.1016/j.phymed.2021.153470

62. Shiming Z, Mak KK, Balijepalli MK, Chakravarthi S, Pichika MR Swietenine potentiates the antihyperglycemic and antioxidant activity of Metformin in Streptozotocin induced diabetic rats. Biomed Pharmacother. 2021;139(March):111576. doi:10.1016/j. biopha.2021.111576 
63. Syamsul ES, Nugroho AE, Pramono S. AKTIVITAS ANTIDIABETES KOMBINASI EKSTRAK TERPURIFIKASI HERBA SAMBILOTO (Andrographis paniculata (Burn.F.) NESS.) DAN METFORMIN PADA TIKUS DM TIPE 2 RESISTEN INSULIN THE ANTIDIABETICS OF COMBINATION METFORMIN AND PURIFIED EXTRACT OF Andrographis paniculata. Maj Obat Tradis. 2011;16(163):124-132.

64. Shengule S, Kumbhare K, Patil D, Mishra S, Apte K, Patwardhan B. Herb-drug interaction of Nisha Amalaki and Curcuminoids with metformin in normal and diabetic condition: A disease system approach. Biomed Pharmacother. 2018;101(October 2017):591598. doi:10.1016/j.biopha.2018.02.032
65. Yim S, You BH, Chae HS, et al. Multidrug and toxin extrusion protein 1-mediated interaction of metformin and Scutellariae radix in rats. Xenobiotica. 2017;47(11):998-1007. doi:10.1080/00498254 2016.1257836

66. Kwon M, Choi YA, Choi MK, Song IS. Organic cation transportermediated drug-drug interaction potential between berberine and metformin. Arch Pharm Res. 2015:38(5):849-856. doi:10.1007/ s12272-014-0510-6

\section{GRAPHICAL ABSTRACT}

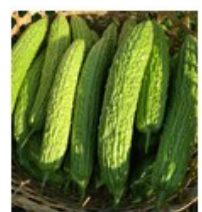

Momordica charantic

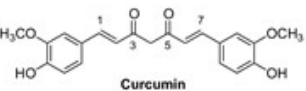

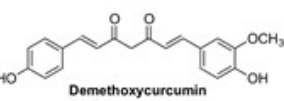

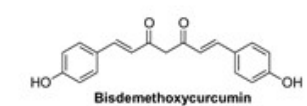

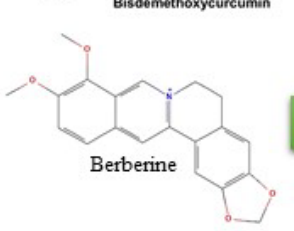<smiles>CCC1CC(C2CCC(C)CC2)CC2C(C)C(C)C(CC)C(CC)C12</smiles>
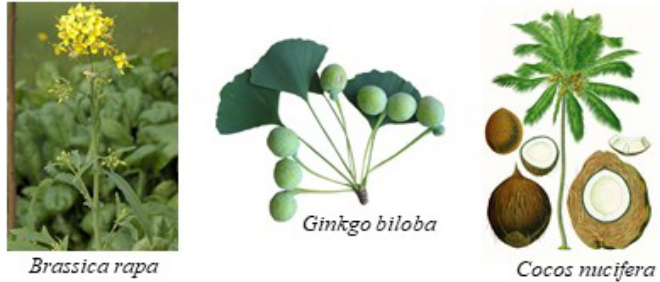

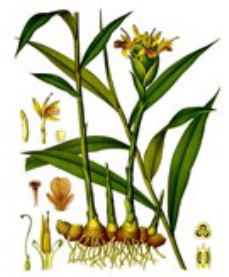

Zingiber officinale

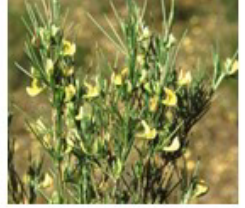

Aspalathus linearis

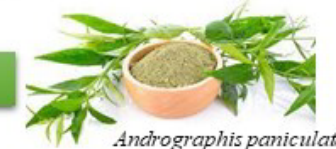

Andrographis paniculata

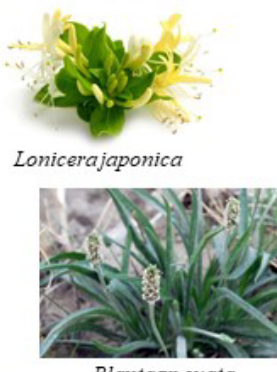

Plantagpovata

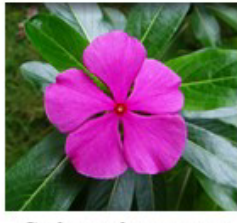

Catharanthus roseous

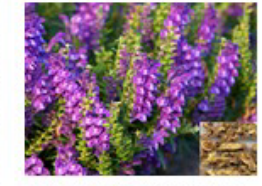

Scutellariabaicalensis 


\section{SUMMARY}

1. Metformin with its various uses such as antidiabetic agent, an effective agent to lose weight for patients with insulin sensitivity problems, obesity patients, anti-tumor agent, anti-cancer potential agent, and also has antiaging potential

2. Metformin could interact with drugs, herbs, and also some bioactive isolate. The interaction might occur pharmacokinetically or pharmacodynamically.

3. Pharmacokinetics interactions occurred during distribution and also excretion via transporters that metformin transported with. This was shown as the elevated or lowered metformin levels in blood.

4. Pharmacodynamics interactions can be seen as the lowering or elevated levels of glucose, $\mathrm{HbA}_{1 \mathrm{c}}$ and even the lipid profile in blood or plasma.

\section{ABOUT AUTHORS}

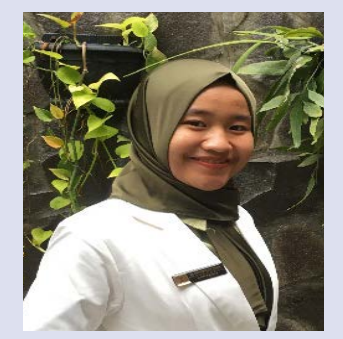

Asri Dwi Endah Dewi Pramesthi: is a magister student at the Faculty of Pharmacy, Universitas Gadjah Mada. Her magister research focused on the pharmacokinetics drugherb interaction of metformin and Momordica charantia.

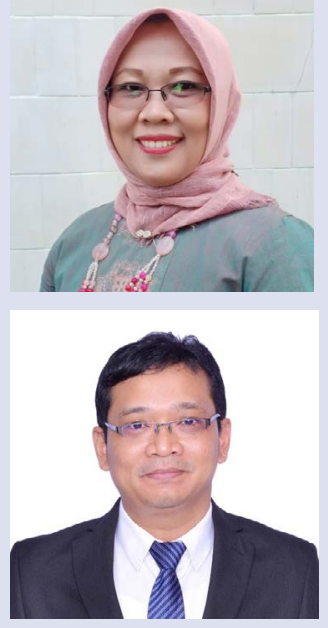

Endang Lukitaningsih: is Vice Dean for Research, Community Services, Collaboration and Alumni of the Faculty of Pharmacy, Universitas Gadjah Mada. Has expertise area in Pharmaceutical analysis, Chemical analysis development for BA/BE, and Cosmeseutical analysis.

Agung Endro Nugroho: is Professor at the Faculty of Pharmacy, Universitas Gadjah Mada. Has expertise area in Basic and Molecular Pharmacology, Clinical Pharmacology, Pharmacodynamics-Pharmacokinetics, and Pharmacotherapy of Gastrointestinal disease.

Cite this article: Pramesthi ADED, Lukitaningsih E, Nugroho AE. Potential Pharmacokinetics and Pharmacodynamics (PK-PD) Drug-Herbs Interactions (DHI) from Metformin and Traditional Medicines: A Literature Review. Pharmacogn J. 2022; 14(1): 235-244. 